\section{Management of Nitrogen and Irrigation in Lettuce Transplant Production affects Transplant Root and Shoot Development and Subsequent Crop Yields}

Puffy Soundy, ${ }^{1}$ Daniel J. Cantliffe, George J. Hochmuth, ${ }^{2}$ and

Peter J. Stoffella ${ }^{3}$

University of Florida, Institute of Food and Agricultural Sciences, Horticultural Sciences Department, 1251 Fifield Hall, PO Box 110690, Gainesville, FL 32611

Additional index words. Lactuca sativa, stand establishment, containerized transplant, nutrition, head size, fertigation

\begin{abstract}
Lettuce (Lactuca sativa L.) 'South Bay' transplant growth and development were evaluated at $0,30,60,90$, and $120 \mathrm{mg} \cdot \mathrm{L}^{-1} \mathrm{~N}$ fertigated at frequencies of every $1,2,3$, or 4 days in a floatation production system to produce plants with optimum roots and shoots which easily pull from trays. Greenhouse experiments (four) were conducted to evaluate root and shoot weight, percent transplant pulling success, and leaf $\mathbf{N}$ content, 28 days after sowing (DAS). Field trials, using transplants produced in Greenhouse experiments 2 and 4 , were conducted to evaluated subsequent yield, head quality characteristics, and leaf $\mathbf{N}$ content. Generally, as $\mathbf{N}$ concentrations increased, dry shoot weight and leaf $\mathbf{N}$ concentration increased, and root:shoot ratios decreased linearly or quadratically. Lettuce transplants grown in a floatation irrigation system fertigated every second to third day with 60 to $90 \mathrm{mg} \cdot \mathrm{L}^{-1} \mathrm{~N}$ resulted in transplants with optimum root systems to achieve the highest pulling success rate from flats. Subsequent yields and head quality were optimum for pretransplant production fertigation $N$ concentration of 60 to $90 \mathrm{mg} \cdot \mathrm{L}^{-1}$, regardless of irrigation frequency.
\end{abstract}

Poor stand establishment of direct-seeded lettuce crops using both pelleted and raw seeds, particularly during conditions of environmental stress, has led to the use of transplants as a means of establishing economically viable plant stands (Cliffe, 1989). Guzman et al. (1989) reported that superior plant stand was the major contributing factor for increased marketable yields from transplanted crisphead and romaine lettuce (Lactuca sativa L.). They concluded that growers in southern Florida, with harsh and unreliable weather, may minimize economic losses and become more consistent suppliers of lettuce if a portion of the crop were transplanted. According to Klassen (1986), other reasons growers were transplanting rather than direct-seeding included improved plant-to-plant uniformity

Received for publication 10 May 2004. Accepted for publication 2 Dec. 2004. Florida Agricultural Experiment Station journal series R-10221. We appreciate the partial support of this project from Speedling, Inc., Sun City, Fla.

${ }^{1}$ Current address: Dept. of Plant Production and Soil Science, Univ. of Pretoria, Pretoria, 0002, South Africa.

${ }^{2}$ Current Address: Univ. of Florida, Institute of Food and Agricultural Sciences, North Florida Research and Education Center, Research Road, Quincy, FL. 32351-5677.

${ }^{3}$ Current Address: Univ. of Florida, Institute of Food and Agricultural Sciences, Indian River Research and Education Center, 2199 South Rock Road, Ft. Pierce, FL. 33945-3138. especially for an once-over harvested crop such as lettuce, early-season weed control, more uniform spacing of plants, and elimination of manual thinning densely seeded rows.

Containerized vegetable transplants grown in greenhouses can either be overhead irrigated, or subirrigated. Using subirrigation (floatation system), Leskovar and Cantliffe (1993) reported improved uniformity and quality of transplants, as compared with overhead irrigation. Drought stress and root pruning methods used to harden and prevent stem elongation in fresh-market tomato (Lycopersicon esculentum Mill.) transplants grown with a floatation system, resulted in an increase in lateral root elongation with a decrease in shoot:root ratio (Leskovar et al., 1994). A reduction in shoot: root ratio and an improvement in water-use efficiency of pepper (Capsicum annuum L.) transplants were also reported by Leskovar and Heineman (1994) when plants were produced via the floatation system of irrigation.

Growers have not been able to produce the highest quality lettuce transplants on a seasonal basis using the floatation system. A well-developed root system is essential so that transplants can be easily pulled from the transplant flat, or easily damaged plants with scorched leaves may result, especially when transplanted in the field onto polyethylene covered raised beds. If shoots are too short, they cannot be easily handled and can be trapped under the polyethylene mulch. When using the floatation system of irrigation, management of fertilization is critical, since high rates of fertilizers, especially $\mathrm{N}$, can increase lettuce transplant shoot growth at the expense of root growth (Masson et al., 1991; Tremblay et al., 1987; Tremblay and Senecal, 1988). Combination of $\mathrm{N}$ concentration with irrigation frequency can have a direct impact on minimizing $\mathrm{N}$ losses from the media due to leaching from excess irrigation. Nutrient requirements for lettuce transplant production using a floatation irrigation system have been reported for P (Soundy et al., 2001a) and K (Soundy et al., 2001b).

This study was conducted to a) determine the optimum fertigation frequency and $\mathrm{N}$ concentration for optimizing lettuce transplant root and shoot growth via a floatation irrigation system, and b) improved subsequent field crop yield and head quality.

\section{Materials and Methods}

Greenhouse experiments. 'South Bay' lettuce transplants were grown in a glass greenhouse located at the University of Florida, Gainesville. Speedling styrofoam planter flats (model F392A; Speedling, Sun City, Fla.) [392 cells of $1.9 \times 1.9 \times 6.3 \mathrm{~cm} ; 10.9 \mathrm{~cm}^{3}$ (length $\times$ width $\times$ depth; volume)], were used for transplant production. A peat + vermiculite + styrofoam bead mix (1:2:1, by volume), with AquaGro wetting agent (Aquatrols, Cherry Hill, N.J.) at $0.2 \mathrm{~kg} \cdot \mathrm{m}^{-3}$, was used for the media. Experiments were conducted over several seasons (Table 1). Transplants were grown with natural photoperiod extended to $16 \mathrm{~h}$ by $1000-\mathrm{W}$, high-pressure sodium lamps (250 $\mu \mathrm{mol} \cdot \mathrm{m}^{-2} \cdot \mathrm{s}^{-1}$ photosynthetic photon flux). Flats were seeded, then covered with a thin layer of vermiculite, overhead irrigated sufficiently to moisten the vermiculite, and transferred to a cooler at $20^{\circ} \mathrm{C}$ for germination. After $48 \mathrm{~h}$, flats were returned to the greenhouse.

In Expt. 1, the influence of irrigation frequency with $\mathrm{N}$ concentration of $100 \mathrm{mg} \cdot \mathrm{L}^{-1}$ on lettuce transplant growth was evaluated. Previous investigations reported that $100 \mathrm{mg} \cdot \mathrm{L}^{-1}$ was used for optimizing P (Soundy et al., 2001a) and $\mathrm{K}$ (Soundy et al., 2001b) concentrations for lettuce transplant production under a floatation irrigation system. Treatments consisted of $0 \%, 20 \%, 40 \%$, and $60 \%$ moisture deficit from field capacity (FC). Flats were weighed twice daily, and irrigation was applied when the flats had lost a predetermined amount of moisture. The $0 \%, 20 \%, 40 \%$, and $60 \%$ moisture deficits were equivalent to irrigation applied every $1,2,2$ to 3 , and 3 to $4 \mathrm{~d}$. Irrigations were conducted by floating flats directly in water or nutrient solution. Transplants were fertigated seven times during the experiment. Fertilizers $\left(\mathrm{mg} \cdot \mathrm{L}^{-1}\right)$ consisted of $100 \mathrm{~N}-30 \mathrm{P}-30 \mathrm{~K}-100 \mathrm{Ca}$, and half-strength Hoagland's solution for micronutrients only (Hoagland and Arnon, 1950). A flat was considered a replication in all greenhouse studies. Arandomized complete block experimental design was used with treatments replicated four times.

Since irrigation frequency influenced subsequent lettuce transplant growth, the effects 
Table 1. Sowing schedule and initial media test (Hanlon et al., 1994) for greenhouse Expts. 1 to 4.

\begin{tabular}{|c|c|c|c|c|c|c|c|c|}
\hline \multirow{3}{*}{$\begin{array}{l}\text { Greenhouse } \\
\text { experiment }\end{array}$} & \multirow{3}{*}{$\begin{array}{c}\text { Sowing } \\
\text { date }\end{array}$} & \multicolumn{7}{|c|}{ Media test ${ }^{z}$} \\
\hline & & \multirow[b]{2}{*}{$\mathrm{pH}$} & \multirow{2}{*}{$\begin{array}{c}\mathrm{EC} \\
\left(\mathrm{dS} \cdot \mathrm{m}^{-1}\right)\end{array}$} & $\mathrm{NO}^{3}-\mathrm{N}$ & $\mathrm{P}$ & $\mathrm{K}$ & $\mathrm{Ca}$ & $\mathrm{Mg}$ \\
\hline & & & & \multicolumn{5}{|c|}{$\left(\mathrm{mg} \cdot \mathrm{kg}^{-1}\right)$} \\
\hline 1 & 18 June & 5.1 & 0.1 & 0 & 1.0 & 16.6 & 1.3 & 4.0 \\
\hline 2 & 23 Feb. & 5.1 & 0.1 & 0 & 0.6 & 12.6 & 1.1 & 4.5 \\
\hline 3 & 27 June & 4.8 & 0.1 & 0 & 0.5 & 13.1 & 1.2 & 4.3 \\
\hline 4 & 18 Sept. & 4.4 & 0.3 & 0 & 0.3 & 20.9 & 1.6 & 3.9 \\
\hline
\end{tabular}

${ }^{\mathrm{z}}$ Concentrations in the saturated paste extract. combination with several irrigation frequencies were evaluated (Expts. 2, 3, and 4.). Transplants in Expts. 2, 3, and 4 were grown with $\mathrm{N}$ application concentrations of $0,30,60,90$, or $120 \mathrm{mg} \cdot \mathrm{L}^{-1}$. Other nutrients were applied at equivalent concentrations to all transplants and consisted of $\left(\mathrm{mg} \cdot \mathrm{L}^{-1}\right) 30 \mathrm{P}-30 \mathrm{~K}-30 \mathrm{Ca}$, and half-strength Hoagland's solution for micronutrients only (Hoagland and Arnon, 1950). Fertigation frequency treatments were subirrigated daily, or every second, third, or fourth day. The experiments were arranged in a randomized complete block design with 20 treatments replicated four times and arranged in a factorial combination of five concentrations of $\mathrm{N}$ and four levels of fertigation frequency.

Plant samples (five per replication) were taken $28 \mathrm{~d}$ after sowing (DAS) for growth measurements. Shoots and roots were dried for $3 \mathrm{~d}$ at $70{ }^{\circ} \mathrm{C}$, weighed, and root to shoot ratios calculated.

Individual lettuce transplants were pulled from a flat (five plants per replication) using a model DPPDial Push-Pull (John Chatillon and Sons, Kew Gardens, N.Y.) attached to a binder clip fastened to the base of the stem. Pulling success $(\%)$ was calculated as the percentage of plants that could be pulled from the transplant flat without any breakage.

Dry shoot samples from each plot were ground to pass a 20-mesh screen and acid-digested for total Kjeldahl $\mathrm{N}$ in all experiments according to Wolf (1982). Subsamples (0.25 g) were weighed into $50 \mathrm{~mL}$ digestion tubes. Sulfuric acid and 30\% hydrogen peroxide were added to the tubes, which were then heated on a digestion block at $375^{\circ} \mathrm{C}$. After the digestion process was completed (a total of $2.5 \mathrm{~h}$ ), the samples were allowed to cool, and deionized water was used to bring the volume to $25 \mathrm{~mL}$. The solutions were filtered through P8 filter papers (Fisher), with a particle retention of $>25 \mu \mathrm{m}$, into $25-\mathrm{mL}$ scintillation vials. The solution samples were then sent to the Analytical Research Laboratory, University of Florida, and $\mathrm{N}$ was determined on a rapidflow analyzer (300 Series; ALPKEM Corp., Wilsonville, Ore.).

Field experiments. Transplants from each treatment in greenhouse Expts. 2 and 4 were transplanted on 23 Mar. and 17 Oct., respectively into an Arredondo fine sandy soil (loamy, siliceous, hyperthermic Grosarenic Paleudults) on raised beds covered with white-on-black polyethylene-mulch $(0.038 \mathrm{~mm}$ thick $)$ at the University of Florida Horticultural Research Unit, Gainesville.

The experiments were arranged in a ran- of $\mathrm{N}$ concentration in the nutrient solution in domized complete block experimental design with 20 treatments replicated four times and arranged in a factorial combination of five concentrations of $\mathrm{N}$ and four levels of fertigation frequency. Preplant fertilizer (13N-0P-10.8K) was applied broadcast and incorporated in the bed at $230 \mathrm{~kg} \cdot \mathrm{ha}^{-1}$. Raised beds spaced $1.2 \mathrm{~m}$ center to center, were fumigated with methyl bromide/chloropicrin (98:2) and then covered with polyethylene mulch. Each plot consisted of 30 transplants planted on double offset rows on the raised bed with a spacing of $30 \mathrm{~cm}$ between plants and between rows on the bed (equivalent to 54,000 plants/ha). After transplanting, $100 \mathrm{~mL}$ of nutrient solution (150 $\mathrm{mg} \cdot \mathrm{L}^{-1} \mathrm{~N}$ from $20 \mathrm{~N}-8.6 \mathrm{P}-16.7 \mathrm{~K}$ ) were applied to each transplant hole as a starter fertilizer. Water was applied twice daily for $20 \mathrm{~min}$ each, using drip irrigation lines placed on the center of the bed with emitters spaced $30 \mathrm{~cm}$ apart. Tensiometers (Irrometer Co., Riverside, Calif.) were used to monitor soil moisture tension in the beds. The root zone area soil tension was maintained at about $-10 \mathrm{kPa}$ according to Hochmuth and Smajstila (1998). Beginning one week after transplanting, fertilizer at $15 \mathrm{~kg} \cdot \mathrm{ha}^{-1}$ $\mathrm{N}$ and $16 \mathrm{~kg} \cdot \mathrm{ha}^{-1} \mathrm{~K}$, supplied from $\mathrm{NH}_{4} \mathrm{NO}_{3}$ and $\mathrm{KNO}_{3}$, was injected weekly using a venturetype injector (Netafim Irrigation, Altamonte Springs, Fla.), with the last application one week before harvest totaling $150 \mathrm{~kg} \cdot \mathrm{ha}^{-1} \mathrm{~N}$ and $180 \mathrm{~kg} \cdot \mathrm{ha}^{-1} \mathrm{~K}$. Cultural management practices were similar to those used commercially in Florida (Maynard, 2003)

At crop maturity, the center 20 plants in a plot were weighed individually, and then 10 heads were assessed for firmness, cut longitudinally for height, diameter, stem, width, and core length. Wrapper leaves were sampled at harvest for analysis of tissue $\mathrm{N}$ according to Wolf (1982) as described previously for greenhouse experiments.

Statistical analyses. Data from each experiment were subjected to analysis of variance (ANOVA) using the Statistical Analysis System (SAS Institute, Inc., Cary, N.C.). In each experiment, (main effects of moisture deficit (main effects of $\mathrm{N}$ concentration or irrigation frequency treatments for greenhouse Expts. 2 to 4 and field Expts. 1 and 2) were partitioned into linear or quadratic polynomial contrasts. Variables that had significant $\mathrm{N}$ concentration $\times$ fertigation frequency interactions were subjected to individual linear or quadratic regression analysis (SAS Institute) for each fertigation frequency treatment.

\section{Results and Discussion}

Greenhouse experiment 1. A greenhouse study was conducted to access the effects of water deficit on lettuce transplant growth. Shoot dry weight and leaf $N$ content increased and shoot to root ratio decreased quadratically with increasing moisture deficit in the media (Table 2). Root dry weights were unaffected by moisture deficit in the media (Table 2). However, greater media moisture deficits resulted in transplants with lower root:shoot ratio indicating that a higher portion of dry weight accumulation occurred in the developing shoot system rather than the root system. Leaf $\mathrm{N}$ concentration increased quadratically as moisture deficit in media increased, suggesting that $\mathrm{N}$ uptake may have been reduced with greater irrigation frequencies. Although root weights were similar among treatments, transplants grown in media near field capacity (FC) (daily irrigation) or $60 \%$ FC (irrigated every 3 to 4 d) were considered inferior since they were difficult to pull (based on subjective observations) from the transplant tray, as compared to $20 \%$ and $40 \%$ moisture deficits. Therefore, subsequent greenhouse experiments were designed to evaluate the interactions of irrigation frequencies and $\mathrm{N}$ concentrations on subsequent transplant growth and pulling success from flats.

Greenhouse experiments 2, 3, and 4. Greenhouse studies were design to evaluate combinations of irrigation frequency and $\mathrm{N}$ concentrations through a floatation irrigation production system (Expts. 2, 3, and 4). Soundy and Cantliffe (2001) have reported that lettuce transplant root and shoot growth increased 15 , 21 , and 28 DAS as $\mathrm{N}$ concentration increased from 0 to $60 \mathrm{mg} \cdot \mathrm{L}^{-1}$ in a floatation irrigation system. However, since transplants (grown in Expt. 1.) could not be easily pulled from the trays and total potential growth was not achieved with $100 \mathrm{mg} \cdot \mathrm{L}^{-1} \mathrm{~N} 28 \mathrm{~d}$ after transplanting (DAT), N concentration range was expanded to include $120 \mathrm{mg} \cdot \mathrm{L}^{-1} \mathrm{~N}$ in subsequent treatment for greenhouse experiment one)

Table 2. Root and shoot characteristics of lettuce transplants ( $28 \mathrm{~d}$ after sowing) as affected by irrigation frequency (greenhouse Expt. 1).

\begin{tabular}{|c|c|c|c|c|}
\hline $\begin{array}{l}\text { Moisture } \\
\text { deficit from } \\
\text { field capacity } \\
(\%)\end{array}$ & $\begin{array}{l}\text { Dry } \\
\text { shoot } \\
\text { wt } \\
(\mathrm{mg})\end{array}$ & $\begin{array}{l}\text { Dry } \\
\text { root } \\
w t \\
(\mathrm{mg})\end{array}$ & $\begin{array}{l}\text { Root } \\
\text { to } \\
\text { shoot } \\
\text { ratio }\end{array}$ & $\begin{array}{c}\text { Leaf } \\
\text { tissue } \\
\mathrm{N} \\
\left(\mathrm{g} \cdot \mathrm{kg}^{-1}\right)\end{array}$ \\
\hline 0 & 49.9 & 21.0 & 0.42 & 17.6 \\
\hline 20 & 69.9 & 23.9 & 0.34 & 18.2 \\
\hline 40 & 73.8 & 20.0 & 0.27 & 22.6 \\
\hline 60 & 84.8 & 22.8 & 0.27 & 26.9 \\
\hline Significance & $\mathrm{Q}^{* *}$ & NS & $\mathrm{Q}^{* *}$ & $\mathrm{Q}^{* *}$ \\
\hline
\end{tabular}

${ }^{\mathrm{z}}$ Moisture deficits from field capacity for $0 \%, 20 \%, 40 \%$, and $60 \%$ is equivalent to ferigation frequency every $1,2,2$ to 3 , and 3 to $4 \mathrm{~d}$, respectively.

NS, ${ }^{* *}$ Nonsignificant or significant at $P=0.01 ; \mathrm{L}=$ linear, $\mathrm{Q}=$ quadratic. 
Table 3. Root and shoot characteristics of lettuce transplants ( $28 \mathrm{~d}$ after sowing) as affected by fertilization $\mathrm{N}$ concentration and irrigation frequency (greenhouse Expts. 2, 3, and 4).

\begin{tabular}{|c|c|c|c|c|c|c|c|c|}
\hline \multirow[b]{2}{*}{ Treatment $^{\mathrm{z}}$} & \multicolumn{2}{|c|}{ Expt. 2} & \multicolumn{3}{|c|}{ Expt. 3} & \multicolumn{3}{|c|}{ Expt. 4} \\
\hline & $\begin{array}{l}\text { Root } \\
\text { to } \\
\text { shoot } \\
\text { ratio }\end{array}$ & $\begin{array}{c}\text { Pulling } \\
\text { success } \\
(\%)\end{array}$ & $\begin{array}{l}\text { Dry } \\
\text { root } \\
w t \\
(\mathrm{mg})\end{array}$ & $\begin{array}{l}\text { Root } \\
\text { to } \\
\text { shoot } \\
\text { ratio }\end{array}$ & $\begin{array}{c}\text { Pulling } \\
\text { success } \\
(\%)\end{array}$ & $\begin{array}{l}\text { Dry } \\
\text { root } \\
\text { wt } \\
(\mathrm{mg})\end{array}$ & $\begin{array}{l}\text { Root } \\
\text { to } \\
\text { shoot } \\
\text { ratio }\end{array}$ & $\begin{array}{c}\text { Pulling } \\
\text { success } \\
(\%)\end{array}$ \\
\hline \multicolumn{9}{|c|}{$\mathrm{N}$ concentration $\left(\mathrm{mg} \cdot \mathrm{L}^{-1}\right)$} \\
\hline 0 & 1.01 & 16 & 4.8 & 1.01 & 3 & 3.7 & 0.86 & 0 \\
\hline 30 & 0.47 & 86 & 28.5 & 0.50 & 73 & 19.2 & 0.48 & 88 \\
\hline 60 & 0.38 & 95 & 26.4 & 0.30 & 65 & 23.3 & 0.32 & 96 \\
\hline 90 & 0.29 & 94 & 25.7 & 0.18 & 69 & 21.8 & 0.22 & 98 \\
\hline 120 & 0.21 & 85 & 19.2 & 0.13 & 43 & 18.9 & 0.16 & 79 \\
\hline Significance & $\mathrm{Q}^{* *}$ & $\mathrm{Q}^{* * *}$ & $\mathrm{Q}^{* *}$ & $\mathrm{Q}^{* *}$ & $\mathrm{Q}^{* *}$ & $\mathrm{Q}^{* * *}$ & $\mathrm{Q}^{* *}$ & $\mathrm{Q}^{* *}$ \\
\hline \multicolumn{9}{|c|}{ Frequency $(\mathrm{F})$} \\
\hline 1 & 0.41 & 74 & 25.1 & 0.41 & 45 & 18.2 & 0.37 & 73 \\
\hline 2 & 0.46 & 83 & 23.2 & 0.43 & 50 & 18.9 & 0.39 & 68 \\
\hline 3 & 0.47 & 79 & 17.6 & 0.49 & 55 & 16.6 & 0.42 & 76 \\
\hline 4 & 0.55 & 65 & 14.2 & 0.53 & 49 & 15.7 & 0.44 & 69 \\
\hline Significance & $\mathrm{L}^{* *}$ & $\mathrm{Q}^{* *}$ & $\mathrm{~L}^{* *}$ & NS & NS & NS & $\mathrm{L}^{*}$ & NS \\
\hline $\mathrm{N} \times \mathrm{F}$ & NS & NS & NS & NS & NS & NS & NS & NS \\
\hline
\end{tabular}

${ }^{2} \mathrm{~N}=$ nitrogen; $\mathrm{F}=$ fertigation frequency.

${ }_{\mathrm{NS}, * * * *}^{*}$ Nonsignificant or significant at $P=0.05$ or $0.01 ; \mathrm{L}=$ linear, $\mathrm{Q}=$ quadratic.

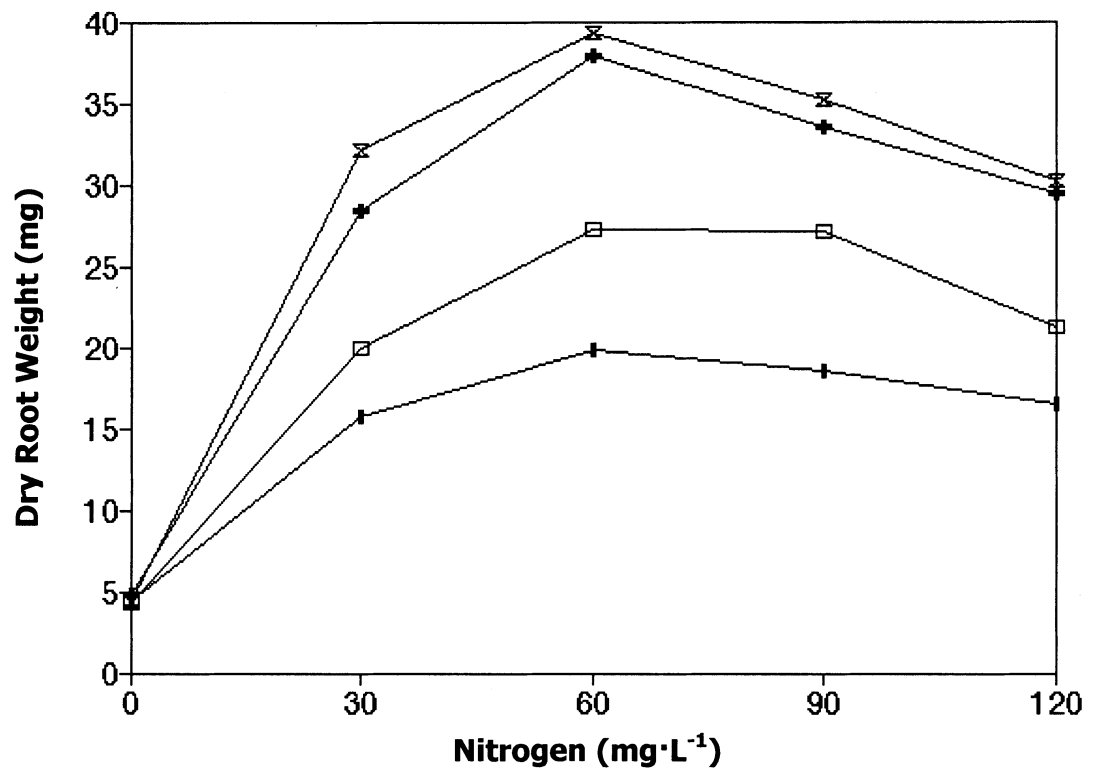

$\approx$ fertig freq $1 ; Q^{*}+-$ fertig freq $2 ; Q^{*}-\square$ fertig freq $3 ; Q^{*} \multimap-$ fertig freq $4 ; Q^{*}$

Fig. 1. Lettuce transplant dry root weight response to fertigation $\mathrm{N}$ concentration and frequency $28 \mathrm{~d}$ after sowing. Expt 2. ${ }^{* *}$ Significant quadratic $(\mathrm{Q})$ regessions at $1 \%$ level.

greenhouse experiments. Irrigation frequency $\times \mathrm{N}$ concentration interactions were significant for dry shoot weight in each experiment. Shoot weights increased as $\mathrm{N}$ concentrations increased, but the rate of increase and shape of the response curve (linear or quadratic) varied with irrigation frequency (data not shown). Root weights increased quadratically as $\mathrm{N}$ concentration increased in greenhouse Expts. 3 and 4 (Table 3 ).

Irrigation frequency had no effect on root weight in Expt. 4, but a linear decrease occurred as irrigation frequency increased in Expt. 3 (Table 3). Irrigation frequency $\times \mathrm{N}$ concentration interaction was significant for root weight in Expt. 2. Root weights increased quadratically as $\mathrm{N}$ concentrations increased (up to $60 \mathrm{mg} \cdot \mathrm{L}^{-1}$ ), but the rate of increase was greater with irrigation frequencies of every 1 or $2 \mathrm{~d}$ (Fig. 1). Root to shoot ratio decreased quadratically as $\mathrm{N}$ concentrations increased in each experiment (Table 3 ), suggesting that increasing $\mathrm{N}$ fertilization resulted in reduced root growth relative to shoot growth. As irrigation frequency decreased, root to shoot ratio linearly increased in Expts. 2 and 4 but had no effect in Expt. 3.

A significant irrigation frequency $\times \mathrm{N}$ concentration interaction occurred for leaf tissue $\mathrm{N}$ concentration in each experiment. Leaf tissue $\mathrm{N}$ concentration linearly or quadratically increased (depending on irrigation frequency) as $\mathrm{N}$ fertilization concentrations increased (data not shown).Higher $\mathrm{N}$ fertilization concentrations increased leaf $\mathrm{N}$ concentration and subsequently increased shoot weights.
It is critical that transplants be completely pulled intact (no stem breakage with complete root system) from the trays to reduce subsequent field transplant loss. Pulling success (\%) improved quadratically as $\mathrm{N}$ concentrations (up to $90 \mathrm{mg} \cdot \mathrm{L}^{-1}$ ) increased in each experiment (Table 3). Therefore, transplants fertilized with $\mathrm{N}$ concentrations at 60 to $90 \mathrm{mg} \cdot \mathrm{L}^{-1}$ and irrigated every 2 to $3 \mathrm{~d}$ resulted in transplants with optimum root growth and subsequent optimum pulling success.

Field experiments. Field experiments were conducted to evaluate effects of lettuce transplant production practices (greenhouse Expts. 2 and 4) on subsequent yields and head quality characteristics (field Expts. 1 and 2, respectively). Irrigation frequency $\times \mathrm{N}$ concentration interactions were not significant for any measured yield or head quality characteristic in either field experiment, therefore only main effects were presented (Tables 4 and 5).

As pretransplant $\mathrm{N}$ concentration (up to 90 $\mathrm{mg} \cdot \mathrm{L}^{-1}$ ) increased, lettuce head weight, height, diameter, stem diameter, and core length increased quadratically in both field experiments. Head firmness rating increased and leaf tissue $\mathrm{N}$ concentration decreased quadratically as pretransplant $\mathrm{N}$ concentrations increased in field Expt. 2 (Table 5) but were similar with increased pretransplant $\mathrm{N}$ concentrations in field Expt. 1 (Table 4). Leaf $\mathrm{N}$ concentrations ranged from 24 to 25 and 34 to $36 \mathrm{~g} \cdot \mathrm{kg}^{-1}$ in field Expts. 1 and 2, respectively. Hochmuth and Clark (1991) reported that leaf $N$ concentrations of 20 to $30 \mathrm{~g} \cdot \mathrm{kg}^{-1}$ were an adequate range for crisphead lettuce production. Transplant fertigation frequency had no effect on subsequent lettuce yields, head quality characteristics, or leaf tissue $\mathrm{N}$ concentration in either field experiment (Tables 4 and 5).

Lettuce transplants grown in a floatation irrigation system with 60 and $90 \mathrm{mg} \cdot \mathrm{L}^{-1} \mathrm{~N}$ concentrations applied every second to third day resulted in transplants with optimum root systems to achieve the highest pull success from flats. Subsequent lettuce yields and head quality were optimum for lettuce transplants produced with 60 to $90 \mathrm{mg} \cdot \mathrm{L}^{-1} \mathrm{~N}$, regardless of irrigation frequency.

\section{Literature Cited}

Cliffe, D.O. 1989. Production and scheduling of lettuce transplants for commercial crop production. Acta Hort. 247:49-51.

Guzman, C., A. Sanchez, and R.T. Nagata. 1989. A comparison of transplanted and direct-seeded lettuce at various levels of soil fertility. Soil Crop Sci. Soc. Fla. Proc. 48:26-28.

Hanlon, E.A., J.G. Gonzalez, and J.M. Bartos, 1994. IFAS extensión soil testing laboratory chemical procedure and training manual. Univ. Fla. IFAS Fla. Coop. Ext. Serv. Circ. 812.

Hoagland, D.R. and D.I. Arnon. 1950. The waterculture method for growing plants without soil. Circ. 347. Calif. Agr. Expt. Sta., Berkeley.

Hochmuth, G.J. and G.A. Clark. 1991. Fertilizer application and management for micro (or drip) irrigated vegetables in Florida. Fla. Coop. Ext. Spec. Ser. Rpt. SS-VEC-45.

Hochmuth, G.J. and A.G. Smajstila. 1998. Fertilizer application and management for micro (drip) irrigated vegetables in Florida. Univ. Fla. IFAS 
Table 4. Effects of $\mathrm{N}$ concentration and fertigation frequency during transplant production (greenhouse Expt. 2) on subsequent lettuce yield and head quality, harvested 11 or 16 May (field Ext. 1).

\begin{tabular}{|c|c|c|c|c|c|c|c|}
\hline Treatment $^{z}$ & $\begin{array}{c}\text { Head } \\
\text { wt } \\
(\mathrm{g})\end{array}$ & $\begin{array}{c}\text { Firm } \\
\text { rating }^{\mathrm{y}} \\
(1-5)\end{array}$ & $\begin{array}{c}\text { Head } \\
\text { ht } \\
(\mathrm{mm})\end{array}$ & $\begin{array}{l}\text { Head } \\
\text { diam } \\
(\mathrm{mm})\end{array}$ & $\begin{array}{l}\text { Stem } \\
\text { diam } \\
(\mathrm{mm})\end{array}$ & $\begin{array}{c}\text { Core } \\
\text { length } \\
(\mathrm{mm})\end{array}$ & $\begin{array}{c}\text { Leaf } \\
\text { tissue } \\
\mathrm{N} \text { conn } \\
\left(\mathrm{g} \cdot \mathrm{kg}^{-1}\right)\end{array}$ \\
\hline \multicolumn{8}{|c|}{$\overline{\mathrm{N}}$ concentration $\left(\mathrm{mg} \cdot \mathrm{L}^{-1}\right)$} \\
\hline 0 & 635 & 4.8 & 129 & 123 & 27 & 71 & 24.7 \\
\hline 30 & 765 & 5.0 & 135 & 137 & 31 & 96 & 24.6 \\
\hline 60 & 801 & 4.8 & 140 & 134 & 29 & 57 & 24.7 \\
\hline 90 & 798 & 4.8 & 142 & 133 & 28 & 57 & 24.6 \\
\hline 120 & 772 & 4.7 & 140 & 132 & 29 & 56 & 24.2 \\
\hline Significance & $\mathrm{Q}^{* *}$ & NS & $\mathrm{Q}^{* *}$ & $\mathrm{Q}^{* *}$ & $\mathrm{Q}^{* *}$ & $\mathrm{Q}^{* *}$ & NS \\
\hline \multicolumn{8}{|l|}{ Frequency $(F)$} \\
\hline 1 & 731 & 4.8 & 137 & 132 & 29 & 66 & 25.1 \\
\hline 2 & 759 & 4.8 & 138 & 133 & 29 & 67 & 24.6 \\
\hline 3 & 764 & 4.8 & 137 & 131 & 29 & 67 & 24.0 \\
\hline 4 & 762 & 4.9 & 138 & 131 & 28 & 69 & 24.6 \\
\hline Significance & NS & NS & NS & NS & NS & NS & NS \\
\hline$\underline{\mathrm{N} \times \mathrm{F}}$ & NS & NS & NS & NS & NS & NS & NS \\
\hline
\end{tabular}

${ }^{\mathrm{z}} \mathrm{N}=$ nitrogen; $\mathrm{F}=$ fertigation frequency.

${ }^{y}$ Lettuce head firmness on a scale of $1=$ loose, $5=$ compact.

${ }^{\mathrm{NS}, * *}$ Nonsignificant or significant at $P=0.01 ; \mathrm{Q}=$ quadratic.

Table 5. Effects of $\mathrm{N}$ concentration and fertigation frequency during transplant production on lettuce yield and head quality characteristics for greenhouse Expt. 4 harvested 20 Dec. (field Expt. 2).

\begin{tabular}{|c|c|c|c|c|c|c|c|}
\hline Treatment ${ }^{\mathrm{z}}$ & $\begin{array}{c}\text { Head } \\
\text { wt } \\
(\mathrm{g})\end{array}$ & $\begin{array}{l}\text { Firm } \\
\text { rating }^{\mathrm{y}} \\
(1-5)\end{array}$ & $\begin{array}{c}\text { Head } \\
\text { ht } \\
(\mathrm{mm})\end{array}$ & $\begin{array}{l}\text { Head } \\
\text { diam } \\
(\mathrm{mm})\end{array}$ & $\begin{array}{l}\text { Stem } \\
\text { diam } \\
(\mathrm{mm})\end{array}$ & $\begin{array}{l}\text { Core } \\
\text { length } \\
(\mathrm{mm})\end{array}$ & $\begin{array}{c}\text { Leaf } \\
\text { tissue } \\
\mathrm{N} \text { conn } \\
\left(\mathrm{g} \cdot \mathrm{kg}^{-1}\right)\end{array}$ \\
\hline \multicolumn{8}{|c|}{$\overline{\mathrm{N} \text { concentration }\left(\mathrm{mg} \cdot \mathrm{L}^{-1}\right)}$} \\
\hline 0 & 400 & 3.3 & 106 & 112 & 21 & 27 & 36.4 \\
\hline 30 & 618 & 4.8 & 116 & 118 & 27 & 39 & 34.2 \\
\hline 60 & 663 & 4.8 & 120 & 120 & 28 & 47 & 34.4 \\
\hline 90 & 688 & 4.7 & 120 & 120 & 29 & 55 & 34.2 \\
\hline 120 & 650 & 4.8 & 119 & 118 & 30 & 53 & 34.1 \\
\hline Significance & $\mathrm{Q}^{* *}$ & $\mathrm{Q}^{* *}$ & $\mathrm{Q}^{* *}$ & $\mathrm{Q}^{* *}$ & $\mathrm{Q}^{* *}$ & $Q^{* *}$ & $\mathrm{Q}^{*}$ \\
\hline \multicolumn{8}{|l|}{ Frequency $(\mathrm{F})$} \\
\hline 1 & 599 & 4.4 & 117 & 118 & 27 & 46 & 35.2 \\
\hline 2 & 598 & 4.4 & 115 & 116 & 27 & 45 & 34.4 \\
\hline 3 & 605 & 4.6 & 118 & 120 & 27 & 45 & 34.7 \\
\hline 4 & 613 & 4.5 & 115 & 117 & 26 & 41 & 34.2 \\
\hline Significance & NS & NS & NS & NS & NS & NS & NS \\
\hline $\mathrm{N} \times \mathrm{F}$ & NS & NS & NS & NS & NS & NS & NS \\
\hline
\end{tabular}

${ }^{{ }^{2} \mathrm{~N}}=$ nitrogen; $\mathrm{F}=$ fertigation frequency.

yettuce head firmness on a scale of $1=$ loose, $5=$ compact.

$\mathrm{NS}^{* *}$ Nonsignificant or significant at $P=0.01 ; \mathrm{Q}=$ quadratic.
Fla. Coop. Ext. Serv. Circ. 1181. 24 Feb. 2004. http://edis.ifas.ufl.edu/cv141.

Klassen, P. 1986. Economics dictate using transplants. Amer. Veg. Grower 34:9-14.

Leskovar, D.I. and D.J. Cantliffe. 1993. Comparison of plant establishment method, transplant, or direct-seeding on growth and yield of bell pepper. J. Amer. Soc. Hort. Sci. 118:17-22.

Leskovar, D.I., D.J. Cantliffe, and P.J. Stoffella. 1994. Transplant production systems influence growth and yield of fresh-market tomatoes. J.Amer. Soc. Hort. Sci. 119:662-668.

Leskovar,D.I. and R.R. Heineman. 1994. Greenhouse irrigation systems affect growth of 'TAM-Mild Jalapeno-1' pepper seedlings. HortScience 29:1470-1474.

Masson, J., N. Tremblay, and A. Gosselin. 1991. Nitrogen fertilization and HPS supplementary 1 lighting influence vegetable transplant production. I. Transplant growth. J. Amer. Soc. Hort. Sci. 116:594-598.

Maynard, D.N., G.J. Hochmuth, C.S. Vavrina, W.M. Stall, T.A. Kucharck, and S.E. Webb. 2003. Lettuce, endive, and escarole production in Florida. In: S.M. Olson and E. Simmone (eds.). Vegetable production guide for Florida. Univ. Fla. IFAS Fla. Coop. Ext. Serv., Gainesville.

Soundy, P. and D.J.Cantliffe. 2001. Improving lettuce transplant quality in response to nitrogen nutrition in a floation production system. Proc. Fla. State Hort. Soc. 114:294-303.

Soundy, P., D.J. Cantliffe, G.J. Hochmuth, and P.J. Stoffella. 2001a. Nutrient requirements for lettuce transplants using a floatation irrigation system I. Phosphorus. HortScience 36:1066-1070.

Soundy, P., D.J. Cantliffe, G.J. Hochmuth, and P.J. Stoffella. 2001b. Nutrient requirements for lettuce transplants using a floatation irrigation system II. potassium. HortScience 36:1071-1074.

Tremblay, N., S. Yelle, and A. Gosselin. 1987. Effects of $\mathrm{CO}_{2}$ enrichment, nitrogen and phosphorus fertilization on growth and yield of celery transplants. HortScience 22:875-876.

Tremblay, N. and M. Senecal. 1988. Nitrogen and potassium in nutrient solution influence seedling growth of four vegetable species. HortScience 23:1018-1020.

Wolf, B. 1982.Acomprehensive system of leafanalysis and its use for diagnosing crop nutrient status. Commun. Soil Sci. Plant Anal. 13:1035-1059. 